\title{
Validation of RT-qPCR Approaches to Monitor Pseudomonas syringae Gene Expression During Infection and Exposure to Pattern-Triggered Immunity
}

\author{
Amy Smith, ${ }^{1}$ Amelia H. Lovelace, ${ }^{1}$ and Brian H. Kvitko ${ }^{1,2, \dagger}$ \\ ${ }^{1}$ Department of Plant Pathology, University of Georgia, Athens, GA, U.S.A.; and ${ }^{2}$ The Plant Center, University of Georgia \\ Accepted 17 November 2017.
}

Pseudomonas syringae pv. tomato DC3000 is an important model plant pathogen, with a fully annotated genome and multiple compatible plant hosts. Very few studies have examined the regulation of $\mathrm{DC} 3000$ gene expression in vivo. We developed a quantitative reverse transcription-polymerase chain reaction assay to monitor transcriptional changes in DC3000 inoculated into Arabidopsis thaliana leaves during disease and exposure to pattern-triggered immunity (PTI). In our approach, bacterial RNA concentrations in total tissue RNA are standardized using $P$. syringae-specific 16 S ribosomal RNA primers. We validated multiple stable reference genes for normalization in calculating the relative expression of genes of interest. We used empirically derived rates of amplification efficiency to calculate relative expression of key marker genes for virulence-associated regulation. We demonstrated that exposure to PTI alters DC3000 expression of type III secretion system, coronatine synthesis genes, and flagellar marker genes.

Pseudomonas syringae pv. tomato DC3000 is a commonly used and powerful model bacterial pathogen of plants. DC3000 is both highly genetically tractable and benefits from a complete genome sequence that has undergone continuous efforts to update and refine its annotation (Buell et al. 2003; Filiatrault et al. 2011; Lindeberg et al. 2009). The capacity of DC3000 to infect both the model plant hosts Arabidopsis thaliana, Nicotiana benthamiana, and the horticultural crop tomato (Solanum lycopersicum), have made it a preferred pathogen for analysis of plant biotic stress, plant microbe interactions, and the study of the plant immune system (Bombarely et al. 2012; Xin and He 2013; Zeng et al. 2011). Pattern-triggered immunity (PTI), one of two major tiers of the plant immune system, confers broad defense against pathogens of multiple classes, typically in the absence of a programmed cell death hypersensitive response (Jones and Dangl 2006; Newman, Sundelin et al. 2013; Nishimura and Dangl 2010; Zipfel and Robatzek 2010). PTI is activated by the binding of pathogen- or microbe-associated

${ }^{\dagger}$ Corresponding author: Brian H. Kvitko; E-mail: bkvitko@uga.edu

Funding: This work was supported by National Institute of Food and Agriculture Hatch grant GEO00791 and the State of Georgia.

*The $\boldsymbol{e}$-Xtra logo stands for "electronic extra" and indicates that three supplementary files are published online.

(C) 2018 The American Phytopathological Society molecular patterns (PAMPs or MAMPs), such as microbial cell-wall components or epitopes of conserved microbial proteins, by cognate surface-displayed pattern recognition receptors (PRRs) (Jones and Dangl 2006). The 22-amino acid peptide epitope of bacterial flagellin Flg22 is recognized by the PRR FLS2 leading to the activation of PTI in the plant host (Zipfel et al. 2004). In Arabidopsis, preinduced PTI restricts DC3000 proliferation and the delivery of protein effectors by the DC3000 type III secretion system (T3SS) (Crabill, Joe et al. 2010, Wei, Chakravarthy et al. 2013). The one or more mechanisms by which PTI restricts T3SS effector delivery are unclear. A potentially fruitful approach that could be used to uncover the mechanisms of PTI would be to monitor DC3000 transcriptomic responses in vivo during PTI exposure.

A handful of transcriptomic approaches have been used to examine the global gene expression patterns of $P$. syringae in vivo. Genetic screening using in vivo expression technology revealed differential expression of many DC3000 genes now known to be virulence-associated as well as many other plant-induced genes whose roles in plants have yet to be determined (Boch et al. 2002). Similarly, microarray analysis has been used to identify $P$. syringae pv. syringae $\mathrm{B} 728$ a genes differentially regulated during epiphytic or endophytic colonization of bean (Yu et al. 2013).

Quantitative reverse transcription-polymerase chain reaction (RT-qPCR) is a well-established and powerful tool for smallscale transcriptomic studies. As a complement to RNA-Seq, RT-qPCR allows researchers to investigate transcriptional changes between experimental conditions in a more focused manner. RT-qPCR has been used routinely to monitor $P$. syringae gene expression in vitro in $h r p$-inducing media (Tegli and Gori et al. 2011; Lee et al. 2015; Vargas et al. 2013; Wei et al. 2000), but only a few studies have examined gene expression in vivo (Mascia et al. 2010; Petriccione et al. 2015; Scholtz and Visser 2013; Tegli and Gori et al. 2011). The study of bacterial transcriptomics within hosts is not straightforward, due to the low and variable amounts of bacterial RNA present across stages of infection amid host and endogenous microbiota RNA. These wide variations in bacterial RNA concentration can make it difficult to standardize all samples to a single bacterial RNA concentration across diverse in-planta treatments. In addition, test condition-appropriate reference genes (RGs) should be validated as stable for normalizing expression of genes of interest (GOI). Without appropriate sample standardization and validated expression normalization, relative expression calculation for target GOI can be skewed.

We sought to address these problems by validating a RTqPCR method to measure DC3000 gene expression directly in 
inoculated Arabidopsis leaves, following the minimum information for publication of quantitative real-time PCR experiments (MIQE) guidelines (Bustin et al. 2009). The MIQE guidelines were published in 2009 to establish a rubric regarding all aspects of RT-qPCR, from sample preparation to data storage. To develop our approach, we generated in-planta samples of different treatment conditions, including early $(5 \mathrm{~h})$ and middle (24 h) infections by DC3000 in Arabidopsis Col0 leaves either pretreated $20 \mathrm{~h}$ prior with Flg22, to activate PTI, or mock-treated, to allow natural disease progression. We developed $P$. syringae-specific primers for the $16 \mathrm{~S}$ ribosomal small subunit RNA (16S ribosomal RNA [rRNA]) to measure the concentrations of bacterial RNAs within mixed RNA samples. We tested the transcriptional stability of six published DC3000 RGs (16S rRNA, gap-1, gyrA, hemD, recA, and rpoD) (Ferreira et al. 2006; Records and Gross 2010; Tegli and Gori et al. 2011; González-Lamothe et al. 2012; Freeman et al. 2013; Vargas et al. 2013; Chatnaparat et al. 2015; Ishiga and Ichinose 2016; Lee et al. 2015) as well as three new RG candidates selected based on a preliminary in-situ RNA-Seq experiment, ultimately validating four for use in our approach ( recA, rpoD, $l e u D$, and $o p r F$ ). Using our protocol for RT-qPCR with multiple validated RGs, we examined the relative expression of three GOI ( $h r p A l, c f l$, and $f l i C)$ relevant to DC3000-host interactions of DC3000 in planta and from in-vitro media.

\section{RESULTS}

\section{Quantification of bacterial RNA from inoculated tissue total RNA.}

For accurate calculation of relative gene expression by RTqPCR, it is important to standardize to a single concentration of bacterial RNA across samples. During the course of infection, DC3000 colony counts within leaf tissue may range by three or more orders of magnitude. One approach that could be used to estimate bacterial RNA in a total tissue RNA sample would be to determine viable bacterial counts by dilution plating and standardize input RNA based on those bacterial counts. Unfortunately, viable count sampling must be conducted from a secondary tissue sample, as the time and processing needed for dilution plating would result in alterations to the bacterial transcriptome. Conversely, RNA-stabilizing techniques would interfere with accurate measurement of viable colony counts. Thus, colony counts must be determined from a second sample collected from the same inoculated tissue used for RNA extraction. We wanted to validate a bacterial RNA quantification method directly linked to the RNA sample to be analyzed by RT-qPCR rather than a method that requires inference from a second tissue sample. By quantifying directly from the analytical sample, any variations between samples in RNA extraction and cDNA conversion are directly incorporated into the RNA quantification measurement. We tested whether DC3000 $16 \mathrm{~S}$ rRNA concentration could be used as an in-sample proxy for bacterial concentration within inoculated tissue, using the rationale that rRNA comprises the major component of total bacterial RNA (Bremer and Dennis 2008) and could thus serve as a reliable measurement of bacterial RNA concentration as a whole. To avoid amplification of endogenous microbiome or chloroplast $16 \mathrm{~S}$ rRNA, specialized $P$. syringae $16 \mathrm{~S}$ primers were designed to prime within $P$. syringae $16 \mathrm{~S}$ variable regions 1 and 2 to improve specificity. In pseudomonads, variable region 1 is hypervariable, allowing for good species specificity in primer design (Bodilis et al. 2012).

To test whether bacterial $16 \mathrm{~S}$ rRNA levels detected by RTqPCR could be used as a proxy for measuring bacterial concentration in planta, plants were inoculated with DC3000 suspensions at five concentrations and were then sampled $5 \mathrm{~h}$ postinoculation (hpi). To determine bacterial concentration and to extract total RNA, book-matched leaf discs punched from left and right sides of individual leaves were carefully distributed for either dilution plating or RNA extraction. We verified that matched leaf-tissue samples collected from the left and right sides of inoculated leaves carry statistically similar amounts of bacteria by dilution plating (Supplementary Data $\mathrm{S} 1$, book-match leaf test). For each sample, we paired the number of viable bacteria per milligram of leaf tissue (CFU/mg leaf tissue) as determined by dilution plating with the concentration of bacterial 16S rRNA (nanograms of 16S rRNA per milligram of leaf tissue), determined by RT-qPCR using $P$. syringae-specific $16 \mathrm{~S}$ rRNA primers. 16S rRNA concentration was determined using a standard curve generated with a synthetic double-stranded DNA gene block (gBlock) of the target 16S rRNA amplicon. Pairing these two metrics (CFU/mg leaf tissue and nanograms of $16 \mathrm{~S}$ rRNA per milligram of leaf tissue, both $\log _{10}$-transformed) against one another for each sample yields a positive linear correlation of CFU per nanogram of bacterial 16S rRNA (Fig. 1A).

This approach could fail if ribosome content per bacterium varied during in-planta treatments or during exposure to PTI. We conducted an experiment to test whether a linear relationship between bacterial count and 16S rRNA is maintained in cells exposed to in-planta conditions that either restrict or permit bacterial growth. In this experiment, cell numbers and 16S RNA levels were determined for DC3000 in mock- or Flg22-pretreated leaves inoculated with one inoculum concentration, and samples were collected at 5 and 24 hpi. Bacterial $\mathrm{CFU} / \mathrm{mg}$ counts were again paired with RT-qPCR-determined 16S rRNA quantities (Fig. 1B). This demonstrated a similar relationship between bacterial counts and 16S RNA per milligram of leaf tissue. As expected, the concentration of bacteria in Flg22-pretreated plants did not increase over the course of $24 \mathrm{~h}$, whereas, during infection of mock-treated plants, the concentration of bacteria increased three logs over the same period (Fig. 1B). Necrosis of plant tissue was observed in mock-treated leaves at 24 hpi but not in Flg22pretreated leaves at the same timepoint (data not shown), confirming effective PTI in Flg22-pretreated samples. Even though there was a difference in growth, these two populations displayed similar cell-to-rRNA ratios. These results support our approach of using RT-qPCR-calculated 16S rRNA concentration as a direct in situ estimate of bacterial RNA concentrations in mixed samples to standardize bacterial RNA input for later steps.

\section{RG selection.}

RGs are necessary to normalize measurements of transcript abundance between samples or experimental treatments. MIQE guidelines call for the use of multiple RGs in calculating transcriptional changes. The ideal RG set would remain transcriptionally stable under different experimental conditions and cover a wide range of expression values, allowing for flexibility of pairing with high- or low-expressed GOI. We identified nine candidate RG genes to test, based on historical utility or new global expression data that suggested they might qualify for use as RGs in these types of studies. Previous studies of $P$. syringae have used gyrA, gap-1, hemD, recA, and rpoD and $16 S$ rRNA as individual RGs (Chatnaparat et al. 2015; Ferreira et al. 2006; Freeman, Chen et al. 2013; GonzálezLamothe et al. 2012; Ishiga and Ichinose 2016; Lee et al. 2015; Records and Gross 2010; Tegli and Gori et al. 2011; Vargas et al. 2013). gap-1 and gyrA showed equal expression under in vitro experimental conditions as measured by microarray (Ferreira et al. 2006). We used previously published qPCR primers for hemD (Freeman et al. 2013) and rpoD 
(González-Lamothe et al. 2012) and designed new primers to target gyrA, gap-1, and recA. The remaining four RG candidates, cynT, lcs-1, leuD, and $o p r F$ were observed as highly expressed and stable in Flg22-pretreated and mock-treated infected plant tissues from a preliminary RNA-Seq analysis (unpublished). We designed new primers for these four candidate RGs as well (Table 1).

\section{RG validation and efficiency estimates.}

The efficiency of PCR is the percentage of perfect doubling of amplicons from cycle to cycle. It can be measured in one of two ways, either from the slope of a curve generated by pairing known quantities (usually serially diluted) of target cDNA to their resulting quantification cycle $\left(\mathrm{C}_{\mathrm{q}}\right)$ values of the PCR or by directly measuring the change in fluorescence per cycle from raw PCR data. The latter is a more direct method and is derived empirically from each sample during RT-qPCR by inputting raw fluorescence data into the software LinRegPCR (LRP), version January2016, available from the Heart Failure Research Center. We compared the PCR efficiency as estimated by the serial-dilution method $\left(\mathrm{E}_{\mathrm{est}}\right)$ to the efficiency derived empirically in LRP ( $\left.\mathrm{E}_{\mathrm{emp}}\right)$ for all primer sets used in this study. $\mathrm{E}_{\mathrm{est}}$ was generally 5 to $10 \%$ higher than its partner $E_{\text {emp }}$ and was often estimated to be greater than $100 \%$ (Table 2).

To measure the stability of the RGs, the differently treated inplanta samples from a preliminary experiment (similar to that illustrated in Figure 1B) and an in-vitro sample were standardized for bacterial RNA using 16S rRNA. These samples were RT-qPCR-amplified with primers targeting all nine candidate RGs; $P$. syringae-specific $16 \mathrm{~S}$ rRNA primers were also used to confirm equal loading. The raw amplification data were input to LRP and the $\mathrm{C}_{\mathrm{q}}$ outputs were measured for variability by RefFinder, available from the cotton expressed sequence tag (EST) database. Candidate RGs were classified by $\mathrm{C}_{\mathrm{q}}$ range (high expressed, 15 to 25 ; mid expressed, 20 to 30 ; low expressed, 25 to 35 ), using the observed $\mathrm{C}_{\mathrm{q}}$ values from preliminary data. The candidate RGs were ranked from most stable (least variability among standardized samples) to least stable (most variability among standardized samples). Of the nine candidate RGs, oprF, recA, leuD, and rpoD were found to be the most stable, in that order; these four genes had verified $\mathrm{C}_{\mathrm{q}}$ ranges from 14 to 30 , as assessed by coefficient of determination $\left(\mathrm{R}^{2}\right)$ values of data plotted from $\mathrm{E}_{\text {est }}$ serial dilutions (Fig. 2). RefFinder's ranking was verified using the GeNorm parameter in SLqPCR, an $\mathrm{R}$ package available from Bioconductor. This module uses the same input $\mathrm{C}_{\mathrm{q}}$ values as well as the target-specific amplification efficiency (also determined in LRP) to score candidate genes for stability. RG rank of stability was identical in both methods.

\section{Using multiple RGs.}

It is increasingly recommended that more than one $\mathrm{RG}$ be used when quantifying relative expression, as there is no "one true" stable RG that is compatible with every given GOI or experimental condition (Bustin et al. 2009; Kozera and Rapacz 2013; Vandesompele et al. 2002). To determine whether the use of single, paired, or multiple RGs would significantly change calculations of the relative expression of a GOI, we calculated the normalized relative quantity (NRQ) using different combinations of RGs. Three biological replicates each of the 24hpi, mock in-planta samples and the in-vitro bacteria samples were standardized to a single $16 \mathrm{~S}$ rRNA quantity $(0.6 \mathrm{pg})$ and were RT-qPCR-amplified against the four validated RGs and $16 \mathrm{~S}$ rRNA. From the resultant $\mathrm{E}_{\mathrm{emp}}$ and $\mathrm{C}_{\mathrm{q}}$ values derived by LRP, we calculated NRQ values using different numbers of RGs (five single RGs, four pairs of RGs, and two combinations of all RGs with and without 16S rRNA) and analyzed for significant differences by analysis of variance $(P<0.05)$. We
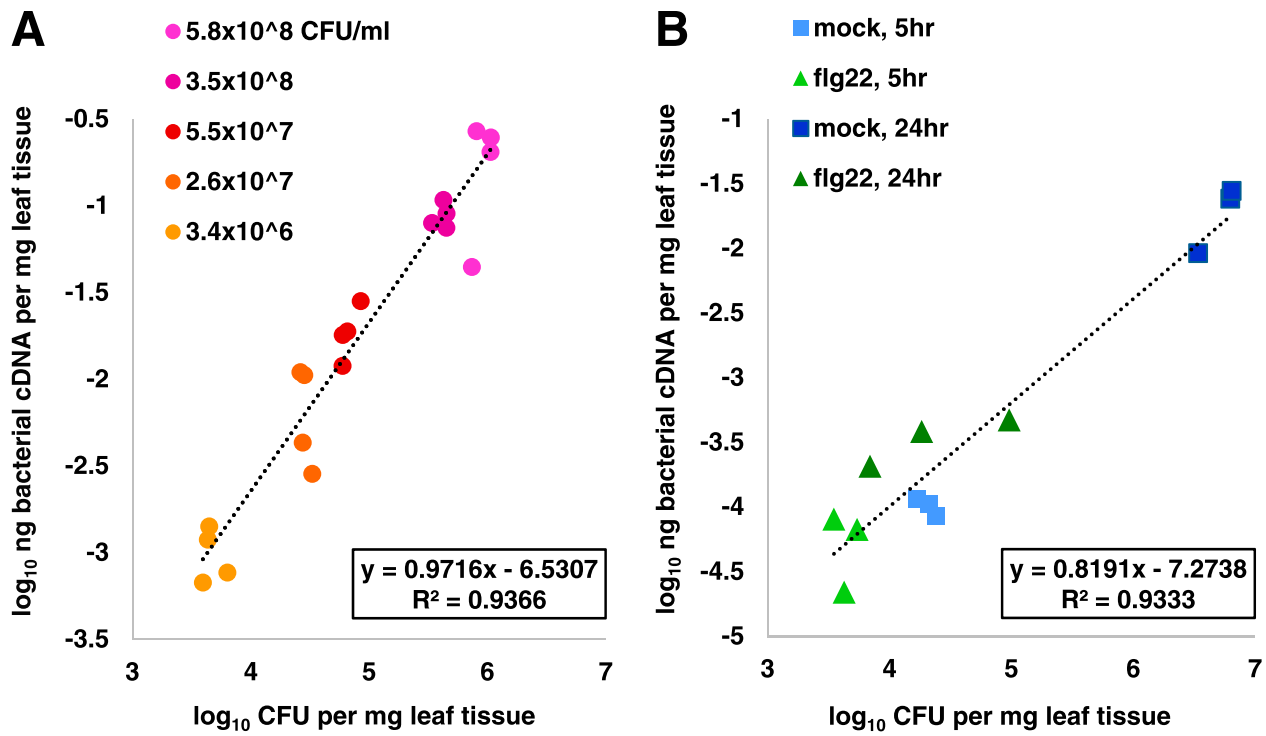

Fig. 1. Correlation of bacteria counts to quantities detected by quantitative reverse transcription-polymerase chain reaction (RT-qPCR). A, Decreasing inoculum concentration results in equivalent detection by RT-qPCR. Arabidopsis leaves were syringe-infiltrated with the indicated concentrations of inoculum and were sampled at $5 \mathrm{~h}$ postinoculation (hpi). A total of $32,0.125-\mathrm{cm}^{2}$ discs were punched from infected leaves and were split for both testing methods. Bacterial colony-forming units per milligram of leaf weight was determined by dilution plating; in the partnered samples, nanograms of $16 \mathrm{~S}$ rRNA per milligram of leaf tissue was calculated by RT-qPCR from a standard curve. Pairing the $\log _{10}$ of each of these measurements yields a strong positive linear correlation with a slope of 0.972 and a coefficient of determination $\left(\mathrm{R}^{2}\right)$ of 0.9366 . Markers on the graph represent individual biological replicates $(n=4)$. B, 16S rRNA can be used as an effective proxy for bacterial load in pattern-triggered immunity-preinduced tissue and at different stages of infection. Plants pretreated 20 hpi with $1 \mu \mathrm{M}$ Flg22 in $0.1 \%$ dimethyl sulfoxide (DMSO) in $0.25 \mathrm{mM} \mathrm{MgCl}_{2}$ were protected from Pseudomonas syringae infection through

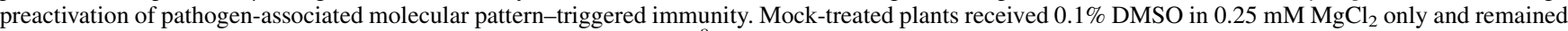
susceptible to infection. Plants were infected with inoculum at $1.9 \times 10^{8} \mathrm{CFU} / \mathrm{ml}$ and were sampled at 5 and $24 \mathrm{hpi}$. Bacterial leaf weight (CFU/mg) was paired with nanograms of $16 \mathrm{~S}$ rRNA per milligram of leaf weight as detected by RT-qPCR. The $\log _{10}$ of each of these measurements still yields a positive linear correlation, with a slope of 0.819 and a $\mathrm{R}^{2}$ value of 0.9333 . Markers on the graph represent individual biological replicates $(n=3)$. 
found that except for $16 \mathrm{~S}$ rRNA, any single RG or any combination of two or more of our four validated RGs gave NRQs that were not significantly different from one another. Based on this, we used $o p r F$ and $r e c A$ together when testing for NRQ. Because they were consistently ranked as most stable, they represent normal and high $\mathrm{C}_{\mathrm{q}}$ ranges for pairing with high- and mid-expressed GOI and they satisfy the MIQE guideline to use more than one RG.

\section{Relative expression of key virulence-regulated genes during infection and PTI exposure.}

To test our approach, we monitored the expression of three key virulence-associated genes comparing expression in vitro from King's B (KB) media to the in-planta conditions of PTI or infection. We selected $h r p A l$ (T3SS hrp pilin), cfl (coronafacic acid ligase), and fliC (flagellin) as marker genes of T3SSassociated genes, the jasmonic acid-mimicking phytotoxin coronatine, and the flagella, respectively. Total RNA from inoculated tissue was isolated after 5 and 24 hpi in Arabidopsis plants pretreated with Flg22, to preinduce PTI, or with a mock treatment, for infection of naive plants. RNA was also extracted from a sample of the bacterial inoculum prepared from $\mathrm{KB}$ media. Six experimental replicates of the in-planta and in-vitro DC3000 samples were standardized for equal loading of bacterial RNA based on $16 \mathrm{~S}$ rRNA. We tested the three target GOI against the two RGs (oprF, recA) and used the in-vitro inoculum sample as a calibrator of relative expression.

PTI exposure affected the regulation of each GOI in ways that suggest dynamic regulatory responses to PTI exposure and infection. First, hrpAl was induced more strongly during PTI exposure than during infection at $24 \mathrm{hpi}$ (Fig. 3A), even though it was similarly expressed both during infection and PTI exposure at 5 hpi (Fig. 3A). Conversely, $c f l$ was differentially induced during infection compared with PTI exposure at $5 \mathrm{hpi}$, but, at $24 \mathrm{hpi}, c f l$ expression was similarly low in both treatments (Fig. 3B). Relative expression of $f l i C$ was downregulated at both 5 and 24 hpi in both treatments but significantly more repressed during infection than during PTI exposure (Fig. 3C).

\section{Comparison of methods to calculate NRQ.}

Using the above data, we compared two methods to calculate relative expression. The $2^{-\Delta \Delta \mathrm{Ct}}$ method (Livak and Schmittgen 2001) assumes all targets amplify at maximum efficiency; a

Table 1. Target genes and corresponding sequences for primers and gBlock

\begin{tabular}{|c|c|c|c|c|c|c|c|}
\hline Gene & Purpose & Annotation & $\begin{array}{l}\text { NCBI gene } \\
\text { designation }\end{array}$ & Primer name & $\begin{array}{l}\text { Primer/gBlock } \\
\text { sequence } 5^{\prime} \text { to } 3^{\prime}\end{array}$ & $\begin{array}{l}\text { Size } \\
\text { (bp) }\end{array}$ & Citations $^{\mathbf{b}}$ \\
\hline$p s 16 S^{\mathrm{c}, \mathrm{d}}$ & Quantification & $\begin{array}{l}\text { Ribosomal } \\
\text { small subunit }\end{array}$ & PSPTO_r01 & $\begin{array}{l}\text { QRT-ps16sV1-F } \\
\text { QRT-ps16sV2-R } \\
\text { 16s-dsDNA-gblock }\end{array}$ & $\begin{array}{l}\text { ACGGGTACTTGTACCTGGTG } \\
\text { CGTTTCCGAGCGTTATCCC } \\
\text { CATGCAAGTCGAGCGGCAGCAC } \\
\text { GGGTACTTGTACCTGGTGGCG } \\
\text { AGCGGCGGACGGGTGAGTAA } \\
\text { TGCCTAGGAATCTGCCTGGTA } \\
\text { GTGGGGGATAACGCTCGGAA } \\
\text { ACGGACGCTAATACCGCATAC }\end{array}$ & 87 & $\begin{array}{l}\text { Tegli and Gori et al. } \\
\text { 2011; González- } \\
\text { Lamothe; El Oirdi } \\
\text { et al. 2012; Lee } \\
\text { et al. } 2015\end{array}$ \\
\hline $\operatorname{cyn} T^{\mathrm{c}, \mathrm{d}}$ & RG & Carbonic anhydrase & PSPTO_5255 & $\begin{array}{l}\text { QRT-cynT-F } \\
\text { QRT-cynT-R }\end{array}$ & $\begin{array}{l}\text { GATTTCCCAATTGCATCACCTG } \\
\text { GCTGGTTTCGATGCTGTAGA }\end{array}$ & 103 & \\
\hline gap $-1^{\mathrm{e}}$ & RG & $\begin{array}{l}\text { Glyceraldehyde- } \\
\text { 3-phosphate } \\
\text { dehydrogenase }\end{array}$ & PSPTO_1287 & $\begin{array}{l}\text { QRT-gap1-for } \\
\text { QRT-gap1-rev }\end{array}$ & $\begin{array}{l}\text { TACGGGTCGGTGTGATAG } \\
\text { CGTGAACTGGGTATCGAAAG }\end{array}$ & 92 & Ferreira et al. 2006 \\
\hline$g y r A^{\mathrm{e}}$ & RG & Gyrase A & PSPTO_1745 & $\begin{array}{l}\text { QRT-gyrA-for } \\
\text { QRT-gyrA-rev }\end{array}$ & $\begin{array}{l}\text { GAAGGGCAGAAGCTGATTT } \\
\text { ACTCAGGGAACTCGGAAA }\end{array}$ & 109 & $\begin{array}{l}\text { Ferreira et al. 2006; } \\
\text { Vargas et al. } 2013\end{array}$ \\
\hline hem $D^{\mathrm{e}}$ & RG & $\begin{array}{l}\text { Uroporphyrinogen-III } \\
\text { synthetase }\end{array}$ & PSPTO_0129 & $\begin{array}{l}\text { QRT-HemD. } \\
\text { F-Freeman } \\
\text { QRT-HemD. } \\
\text { R-Freeman }\end{array}$ & $\begin{array}{l}\text { TCAGCAGCAGTCTGCCTTTA } \\
\text { GTTGCTGAACCCACACTGAA }\end{array}$ & 196 & Freeman et al. 2013 \\
\hline$l s c-1^{\mathrm{c}, \mathrm{d}}$ & RG & Levansucrase & PSPTO_1453 & $\begin{array}{l}\text { QRT-1sc1-F } \\
\text { QRT-1sc1-R }\end{array}$ & $\begin{array}{l}\text { TCTTTGGTGGTCGTGTAATGG } \\
\text { GGTGTGACGCAGGTGTAATAA }\end{array}$ & 118 & \\
\hline $\operatorname{leu} D^{\mathrm{c}, \mathrm{d}}$ & RG & $\begin{array}{l}\text { Isopropylmalate } \\
\text { dehydratase }\end{array}$ & PSPTO_2174 & $\begin{array}{l}\text { QRT-leuD-F } \\
\text { QRT-leuD-R }\end{array}$ & $\begin{array}{l}\text { AGCCTTTACCCAGCACAATG } \\
\text { CGCTTGATCGACTTGAGAAACT }\end{array}$ & 99 & \\
\hline$o p r F^{\mathrm{c}, \mathrm{d}}$ & RG & Outer membrane porin & PSPTO_2299 & $\begin{array}{l}\text { QRToprF-for } \\
\text { QRToprF-rev }\end{array}$ & $\begin{array}{l}\text { GGCTTGGCCATTGGTACTAT } \\
\text { GCGCTGTCGTACATTTCTTTC }\end{array}$ & 110 & \\
\hline$r e c A^{\mathrm{e}}$ & RG & $\begin{array}{l}\text { DNA damage } \\
\text { homologous repair }\end{array}$ & PSPTO_4033 & $\begin{array}{l}\text { QRT-recA-F } \\
\text { QRT-recA-R }\end{array}$ & $\begin{array}{l}\text { TAGAACTTCAGCGCGTTACC } \\
\text { GCCAACTGCCTGGTTATCT }\end{array}$ & 101 & $\begin{array}{l}\text { Records and } \\
\text { Gross } 2010\end{array}$ \\
\hline$r p o D^{\mathrm{e}}$ & RG & $\sigma 70$ & PSPTO_0537 & $\begin{array}{l}\text { QRTrpoD-F/Bouarab } \\
\text { QRTrpoD-R/Bouarab }\end{array}$ & $\begin{array}{l}\text { TGGGTCGTGAGCAGAAG } \\
\text { CGGATGATGTCTTCCACC }\end{array}$ & 94 & $\begin{array}{l}\text { González-Lamothe } \\
\text { et al. 2012; } \\
\text { Chatnaparat et al. } \\
\text { 2015; Ishiga and } \\
\text { Ichinose } 2015\end{array}$ \\
\hline$c f l$ & GOI & $\begin{array}{l}\text { Coronafacic acid } \\
\text { ligase }\end{array}$ & PSPTO_4680 & $\begin{array}{l}\text { QRT-cflF } \\
\text { (collmer jnw123) } \\
\text { QRT-cflR } \\
\text { (collmer jnw124) }\end{array}$ & $\begin{array}{l}\text { TGCTCGTCTCGTCGCCAAG } \\
\text { CGATACCCTTAGTTAGTC } \\
\text { CTGTGG }\end{array}$ & 99 & Worley et al. 2013 \\
\hline $\mathrm{fliC}^{\mathrm{c}}$ & GOI & Flagellin & PSPTO_1949 & $\begin{array}{l}\text { QRT-fliC-for } \\
\text { QRT-fliC-rev }\end{array}$ & $\begin{array}{l}\text { TACCAATCTGAACGGCAAGAA } \\
\text { GCGCTCAAAGTCAGAGAGAT }\end{array}$ & 108 & \\
\hline $\operatorname{hrpA} 1^{\mathrm{c}}$ & GOI & $\mathrm{T} \mathrm{SS}^{\mathrm{e}}$ pilin & PSPTO_1381 & $\begin{array}{l}\text { QRT-hrpA-for } \\
\text { QRT-hrpA-rev }\end{array}$ & $\begin{array}{l}\text { AAGCCAAGGCCAGTAAAG } \\
\text { GGTCTGCTTCTTCATTGTTTC }\end{array}$ & 83 & \\
\hline
\end{tabular}

a $\mathrm{NCBI}=$ National Center for Biotechnology Information, RG = reference gene, GOI = gene of interest, and T3SS = type III secretion system.

${ }^{\mathrm{b}}$ Citations provided when primer sequences were previously published.

${ }^{c}$ Primers and synthetic gBlock was designed from the GenBank accessions of Pseudomonas syringae pv. tomato DC3000 (NC_004578.1).

d Candidate RGs selected from preliminary RNA-Seq data.

e Candidate RGs selected from previously published results. 
modified rearrangement of the equation allows users to input multiple or different efficiencies, or both, specific to each target and to incorporate more than one RG (Pfaffl 2001; Vandesompele et al. 2002) NRQ calculated via the modified equation was more conservative and less variable compared with the calculation using Livak's equation. While the difference in both measurements is slight, we chose to use the modified Pfaffl equation with LRP-transformed data, as it is a better, more precise approach toward presenting RT-qPCR data.

\section{DISCUSSION}

Our objective with this study was to validate a RT-qPCR approach to quantify relative expression of DC3000 transcripts in planta during infection and PTI exposure. To achieve this, we designed $P$. syringae-specific $16 \mathrm{~S}$ rRNA primers for RT-qPCR analysis on the hypothesis that ribosomal RNA accounted for the vast majority of the RNAs isolated from bacteria, and thus, ribosomal quantification should serve as an appropriate proxy for bacterial quantification. Using 16S RNA concentration in place of total bacterial RNA concentration may not be appropriate under all circumstances. Ribosome number per cell may vary under certain growth conditions. However, fundamentally, as rRNA comprises more than half of total RNA, total RNA standardization for RT-qPCR is always weighted toward rRNA content. For the conditions we have tested, we were able to show that 16S rRNA served as a sufficient proxy for measuring quantities of bacteria in both infection of naïve plants and under Flg22-pretreated, PTI-preinduced conditions. This allowed us to effectively standardize DC3000 RNA concentrations for downstream analysis. Without correct standardization between samples, the resultant data from RG validation or relative expression measurements may be misleading. We went to great lengths to carefully pair the CFU/mg leaf tissue and $16 \mathrm{~S}$ rRNA measurements for both methods from the same inoculated leaves and to pair the data appropriately. We found a linear positive correlation of $\mathrm{CFU} / \mathrm{mg}$ leaf tissue to $16 \mathrm{~S}$ rRNA measurements, indicating that bacterial concentration can be calculated based on the quantity of $16 \mathrm{~S}$ rRNA in a sample.

Table 2. Estimated efficiency and empiric efficiency of quantitative reverse-transcription polymerase chain reaction primer sets used in this study

\begin{tabular}{lcc}
\hline Gene & Serial dilutionE $\mathbf{E s t}_{\mathbf{e s t}}\left(\mathbf{R}^{\mathbf{2}}\right)^{\mathbf{a}}$ & LRP $^{\mathbf{b}} \mathbf{E}_{\mathbf{e m p}}(\mathbf{S D})^{\mathbf{c}}$ \\
\hline ps16S & $104.66(0.9980)$ & $95.24(2.398)$ \\
oprF & $102.45(0.9996)$ & $88.26(0.577)$ \\
recA & $89.55(0.9970)$ & $88.44(0.276)$ \\
leuD & $94.73(0.9902)$ & $86.94(0.7333)$ \\
rpoD & $100.53(0.9946)$ & $90.78(0.248)$ \\
hemD & $96.84(0.9865)$ & $91.06(0.607)$ \\
gyrA & $88.43(0.8631)$ & $88.95(1.202)$ \\
gap-1 & $97.20(0.9984)$ & $90.12(0.649)$ \\
lcs-1 & $95.24(0.9986)$ & $89.38(0.360)$ \\
cynT & $82.35(0.9729)$ & $89.68(0.042)$ \\
\hline
\end{tabular}

a Plotting quantification cycle values $\left(\mathrm{C}_{\mathrm{q}}\right)$ of known, serially diluted cDNAs from media-raised bacteria yields a standard curve. The slope of the curve estimates the efficiency $\left(\mathrm{E}_{\text {est }}\right)$ of amplification between samples, as $\mathrm{C}_{\mathrm{q}}$ correlates to quantity. The coefficient of determination of standards to form the curve is measured by the $\mathrm{R}^{2}$ value and is the only metric of variation or quality for $\mathrm{E}_{\mathrm{est}}$

${ }^{b}$ LinRegPCR (LRP) derives the efficiency of individual polymerase chain reactions according to linear regression of raw amplification data for individual reactions and, then, calculates a mean empiric efficiency $\left(\mathrm{E}_{\text {emp }}\right)$ for all reactions within an amplicon group.

${ }^{c} \mathrm{SD}$ is a measurement of variation of the mean $\mathrm{E}_{\mathrm{emp}}$ reported by LRP of each target across multiple experiments and, thus, reports on the consistency of $\mathrm{E}_{\mathrm{emp}}$ across different assays.
Using RefFinder and the SLqPCR R-package, we were able to validate four RGs (oprF, recA, leuD, and $r p o D)$ for use in this experiment. Our panel of RGs cover normal and high $\mathrm{C}_{\mathrm{q}}$ ranges (corresponding to medium- and low-expressed transcripts), refer to different cellular functions, and were demonstrated to be stable within the conditions tested in this experiment. However, it is entirely possible that they will not be stable under other experimental conditions or in other hosts. This panel of RGs has been validated for use in vitro with King's B media and for use in Arabidopsis over short time scales of $24 \mathrm{~h}$ or less, with and without Flg22 induction of PTI. The use of these RGs under other experimental conditions without validation of stability is not recommended without additional validation. Our analysis indicates that any combination of these four RGs can be used to normalize against a GOI, which affords us some

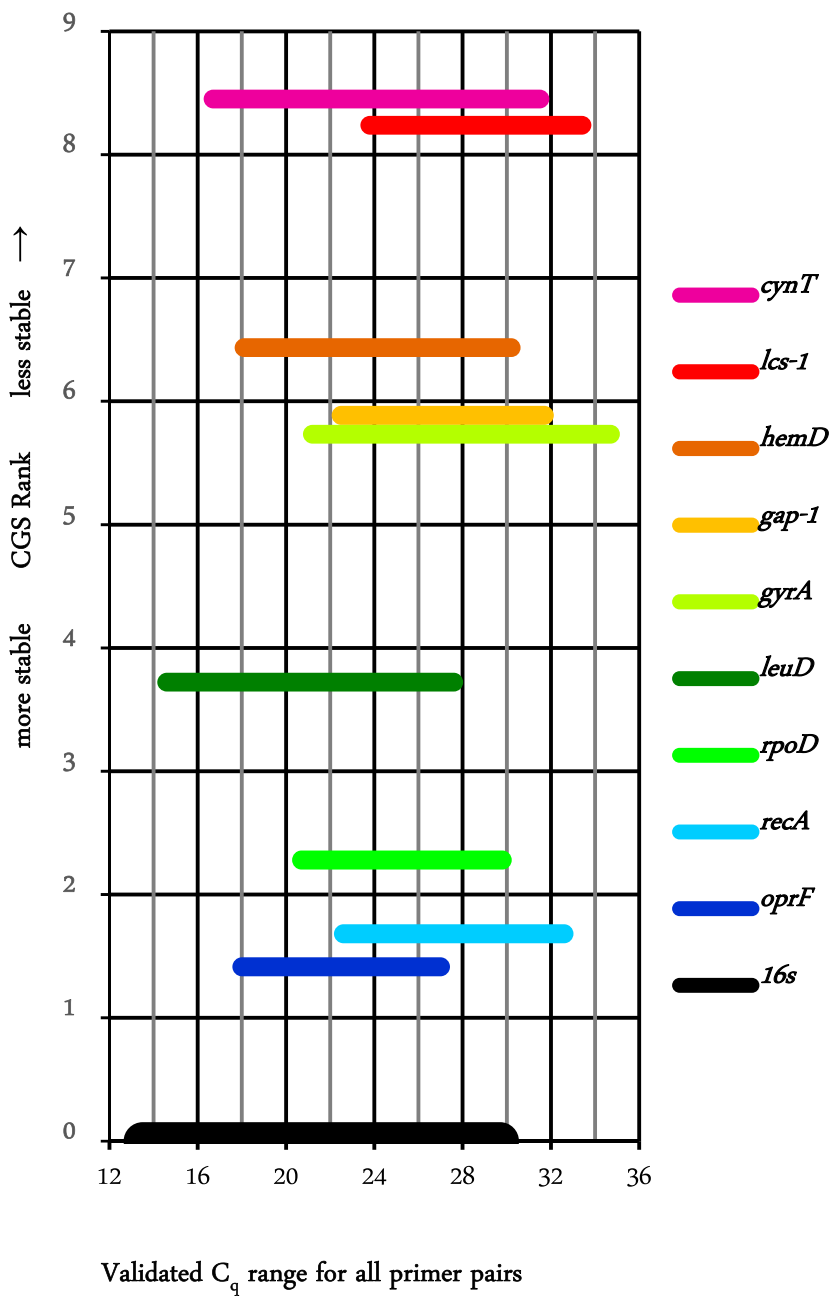

Fig. 2. Comprehensive gene stability (CGS) rank and quantification cycle (Cq) ranges of candidate reference genes (RGs). CGS ranking for each RG is plotted along the $y$ axis, with lower CGS values indicating more stability of expression and larger CGS values indicating decreasing stability. CGS is ranked in the RefFinder meta-analysis software by finding the geometric mean of scores of four unique stability-ranking algorithms (delta $\mathrm{Ct}$, BestKeeper, NormFinder, and Genorm), according to the similarity of $\mathrm{Cq}$ values for templates of equal concentration generated under varying growth conditions. Along the $x$ axis, we show Cq outputs from different template concentrations of cDNA ( 0.0032 to 20.0 ng per quantitative reverse-transcription polymerase chain reaction reaction [PCR]) made from DC3000 grown on King's B media, which indicates a functional range of expected $\mathrm{Cq}$ values for each RG as well as whether a gene is reasonably detectable within the limits of a 40-cycle PCR. 16S rRNA is represented here to show its $\mathrm{Cq}$ range but was not included in stability calculations. 
selection in future experiments for GOI of different ranges of expression or metabolic pathways.

By our calculations, there is often a $10 \%$ overestimation of PCR efficiency when using the serial dilution method as opposed to that derived by LRP. Technical bulletins and the MIQE guidelines (Bustin, Benes et al. 2009) accept up to $110 \%$ efficiency, attributing this to user error. Livak's original $2^{-\Delta \Delta \mathrm{Ct}}$ method to calculate relative expression (Livak and Schmittgen 2001) assumed that PCR efficiency was perfect or at least identical between amplicons. Users of this method gain rough approximates of relative expression, but the equation posed by Pfaffl improved measurements of NRQ, because it allows the user to incorporate efficiencies other than 100\% (Pfaffl 2001), which allows users to compare relative expression across multiple GOI. One challenge with the Pfaffl equation was that it could normalize only against a single $\mathrm{RG}$, which either requires the user to match their GOI with inappropriate but historically used RGs or to seek and validate a new RG for each experiment. The modified Pfaffl equation incorporates multiple RGs, which can satisfy multiple conditions and maintain experimental consistency over time (Hellemans et al. 2007). Many software packages exist to assist users in statistical analysis of qPCR, but few can accommodate the entire qPCR data workflow with sufficient statistical rigor and yet remain both user-friendly and freely available (Pabinger et al. 2014). Our approach utilizes commonly used and free software.

Most users estimate the efficiency by the serial dilution of samples; this is both prone to error and is reagent-consuming. Inputting raw amplification values into LRP allows the user to accurately and immediately derive PCR efficiency in situ for each sample, which contributes to more precise and conservative measurements of NRQ. This particularly benefits quantitative transcriptomic studies in host-pathogen model systems in which the pathogen transcripts are the target of interest, as they are often in low abundance relative to the host's and, therefore, more subject to miscalculation.

As a test of our RT-qPCR method, we examined the NRQ of the virulence-marker genes $h r p A l$ and $c f l$ as well as $f l i C$, a primary pathogen-associated molecular pattern that induces PTI in Arabidopsis. The hrpAl gene encodes the pilin for the T3SS extracellular appendage used for the delivery of T3SS protein effectors into plant cells (MacLean and Studholme 2010; Wei et al. 2000). At 5 hpi, hrpAl expression increases five-fold relative to in vitro in infections of both infected and immune-induced plants, suggesting that bacteria are expressing their T3SS and effectors under both treatment conditions. By 24 hpi, NRQs of hrpAl are reduced but significantly less so in

Fig. 3. Relative expression of three genes of interest (GOI). Expression of three GOI of in-planta samples relative to expression of DC3000 grown in vitro on King's B media, normalized against the expression of two reference genes, oprF and recA. Each box plot is formed from six biological replicates, except 5-h postinoculation (hpi) Flg22, for which $n=5$. $T$ tests (twotailed, assuming equal variances) were conducted between mock and Flg22 samples for both timepoints. The dashed line indicates 0 fold change compared with in vitro DC3000. Single asterisks indicate significant differences with $P<0.05$; double asterisks indicate $P<0.01$. A, Type III secretion system pilin. At $5 \mathrm{hpi}$, expression of $h r p A l$ is up in both mockand Flg22-pretreated bacteria relative to media-raised bacteria, but there is no significant difference between treatments. By $24 \mathrm{hpi}$, expression of hrpAl is reduced in both samples, more so in the mock-treated sample. $\mathbf{B}$, Coronafacic acid ligase. When compared with media-raised bacteria, expression of $c f l$ at 5 hpi is induced in mock-treated plants but is repressed in bacteria exposed to Flg22-pretreated plants. No significant difference exists between mock and Flg22-pretreated leaves at 24 hpi. C, Flagellin. fliC is negatively expressed in all in-planta treatments compared with mediaraised bacteria. For both timepoints, $\mathrm{fliC}$ is significantly repressed in $\mathrm{Flg} 22$ pretreated samples compared with mock-treated plants.
PTI-induced plants. We speculate that, by this time, infection is firmly established in naive plants, the T3SS is functionally assembled, and effectors have been translocated and T3SS gene expression is no longer necessary. In immune-induced plants, effector delivery is blocked and the T3SS pilus structural gene is strongly expressed. Together, these data suggest that the cues that stimulate downregulation of T3SS pilus production over the course of an infection are not present or detected in the PTIstimulated plant environment.
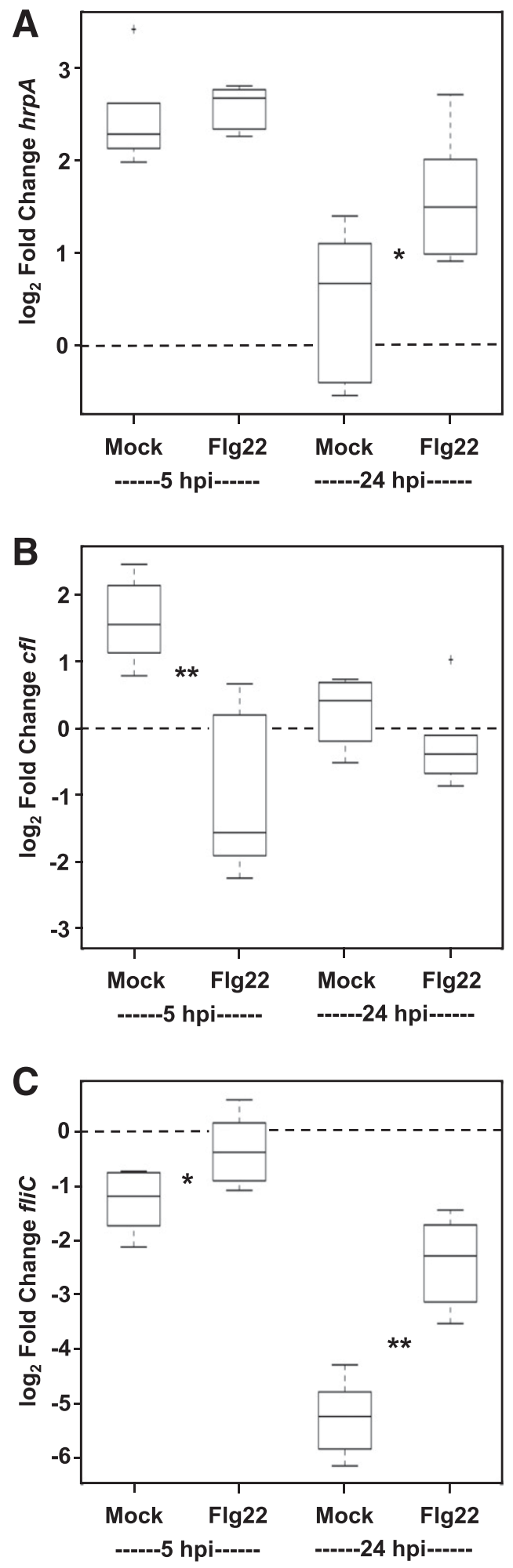
The $c f l$ gene codes for coronafacic acid ligase, a key enzyme involved in the production of the phytotoxin coronatine, which is a structural mimic of jasmonyl-L-isoleucine and a potent activator of jasmonic acid signaling (Katsir et al. 2008; Zhang et al. 2015). Coronatine is associated with the reopening of closed stomata to aid bacterial invasion of leaf tissue (Mittal and Davis 1995; Zheng et al. 2012). Five hours into infection, we observed that, compared with the inoculum baseline, NRQ increased roughly threefold for $c f l$ in bacteria during infection. However, in Flg22-pretreated plants, $c f l$ decreased by threefold, on average. By $24 \mathrm{hpi}$, quantities of $c f l$ in planta under both treatments returned to the baseline expression seen with the KB media-raised inoculum, indicating a temporal limit to coronatine synthesis gene expression in this plant-pathogen system.

In contrast, NRQ of fliC (flagellin) was repressed by $5 \mathrm{~h}$ and more strongly repressed by $24 \mathrm{~h}$ during infection. However, during PTI exposure, $\mathrm{fliC}$ was only observed as repressed at $24 \mathrm{~h}$ and the repression was weaker than what was observed during infection. Flagellin is a potent PAMP or MAMP recognized by many plants, so it may be evolutionarily advantageous to reduce flagellin expression during plant-host interactions to reduce host PTI signaling (Boller and Felix 2009; Zipfel et al. 2004). This is supported by observations of the active repression of flagella seen in $P$. syringae pv. maculicola under T3SS-inducing conditions (Schreiber and Desveaux 2011). The repression of flagellin may also represent an adaptation by $P$. syringae to prevent mis-targeting of effector proteins for secretion through the flagellar pathway and vice versa (Wei et al. 2013).

In conclusion, we have validated a $16 \mathrm{~S}$ rRNA quantification as an effective approach for standardizing the amount of DC3000 RNA collected from inoculated tissue samples from diverse treatments and timepoints. We also validated a set of four stable DC3000 RGs for RT-qPCR expression normalization of DC3000 transcripts during PTI exposure and infection of Arabidopsis. A detailed protocol for this approach is provided in Supplementary Files S2 and S3. We have used our approach to demonstrate that PTI exposure alters the expression of key DC3000 virulence-associated pathways. It is our hope that this approach will find utility among researchers seeking to discern the mechanisms of PTI action and support efforts at global transcriptomics analysis of this important model plant pathogen.

\section{MATERIALS AND METHODS}

\section{Culture preparation.}

Inoculum was prepared by streaking fresh $P$. syringae pv. tomato DC3000 colonies onto a KB agar with $60 \mu \mathrm{g}$ of rifampicin (Rf) per milliliter (King et al. 1954), incubating in the dark for 1 day at room temperature, and smearing the culture in $0.4 \mathrm{ml}$ of liquid media to create a lawn, followed by similar incubation. A small patch of lawn was suspended into $0.25 \mathrm{mM}$ $\mathrm{MgCl}_{2}$, and the optical density at $600 \mathrm{~nm}\left(\mathrm{OD}_{600}\right)$ was brought to 0.9 , equivalent to $1 \times 10^{9} \mathrm{CFU} / \mathrm{ml}$, using a BioSpectrometer (Eppendorf, Hamburg, Germany). This suspension was further diluted in $0.25 \mathrm{mM} \mathrm{MgCl} 2$, to be used as inoculum. Actual concentration of inoculum was obtained by serial dilution and plating onto $\mathrm{KB}$ media with $\mathrm{Rf}$. Plates were incubated at room temperature for $24 \mathrm{~h}$ and were then moved to $4^{\circ} \mathrm{C}$ for 3 days, before counting visible colonies to calculate $\mathrm{CFU}$ per milliliter.

\section{Infected plant tissue preparation.}

To test that bacteria were equally dispersed throughout the apoplastic space of infiltrated leaves, five fully expanded leaves of a similar developmental stage from 4- to-5-week-old Arabidopsis thaliana $\mathrm{Col}-0$ plants $\left(23^{\circ} \mathrm{C}\right.$ continuous, $14 \mathrm{~h}$ of light and $10 \mathrm{~h}$ of dark, low intensity lighting) were infiltrated using a blunt syringe with a suspension of $P$. syringae pv. tomato DC3000 (OD 0.288, $\left.3 \times 10^{8} \mathrm{CFU} / \mathrm{ml}\right)$ in $0.25 \mathrm{mM} \mathrm{MgCl} 2$. Plants were allowed to dry for $1 \mathrm{~h}$ at room temperature. Using biopsy punches (Integra Life Sciences, Plainsboro, NJ, U.S.A.), eight $0.125-\mathrm{cm}^{2}$ discs were excised along both sides of the midvein of each leaf, creating two book-matched sets of four discs. Each set was ground in $100 \mu$ of $0.25 \mathrm{mM} \mathrm{MgCl}_{2}$, were then serial-diluted and plated in triplicate on $\mathrm{KB}+\mathrm{Rf}$, and were incubated as above, to obtain CFU/mg leaf tissue values. Concentrations of bacteria (CFU per square centimeter) recovered from left and right sides of individual leaves were determined. We used a student's $t$ test (paired two-sample for means, $P<0.5$ ) in Excel 2016 (Microsoft, Redmond, WA, U.S.A.) to compare concentrations between the left and right sides of individual leaves, assuming a null hypothesis of no difference.

To compare in planta bacterial concentrations as determined by dilution plating and by $16 \mathrm{~S}$ quantification in RT-qPCR, fully expanded leaves of four Arabidopsis plants were similarly infiltrated with one of five decreasing inoculum concentrations of DC3000 in $0.25 \mathrm{mM} \mathrm{MgCl}_{2}$, from approximately $10^{9}$ to $10^{6}$ $\mathrm{CFU} / \mathrm{ml}$. Four discs were excised from both sides of the midvein of four leaves from each plant, for a total of 32 discs per plant. A total of 16 discs from the left sides of leaves were pooled and weighed together before being ground in $400 \mu \mathrm{l}$ of $0.25 \mathrm{mM} \mathrm{MgCl}_{2}$, and then, serial-diluted and plated on $\mathrm{KB}+\mathrm{Rf}$ to obtain the CFU per milligram of leaf tissue concentrations as above. The remaining 16 discs from the right sides of leaves were frozen in liquid nitrogen for RNA extraction. Each plant was considered a biological replicate $(n=4)$.

For collecting samples from PTI-induced leaves, two Arabidopsis plants were pretreated by leaf infiltration with $1 \mu \mathrm{M}$ Flg22, in $0.1 \%$ dimethyl sulfoxide (DMSO), and $0.25 \mathrm{mM}$ $\mathrm{MgCl}_{2}, 20 \mathrm{~h}$ prior to infection. Two additional plants were mock-treated with an equal volume of $0.1 \%$ DMSO and $0.25 \mathrm{mM} \mathrm{MgCl}$. Individual leaves were syringe-infiltrated with an approximately $2 \times 10^{8}$ concentration of DC3000 in $0.25 \mathrm{mM} \mathrm{MgCl}_{2}$. Two whole leaves from two plants per treatment were harvested at 5 and $24 \mathrm{~h}$ postinfection. A single disc was excised from each leaf; the four discs were pooled and weighed together before being ground in $100 \mu \mathrm{l}$ of $0.25 \mathrm{mM}$ $\mathrm{MgCl}_{2}$, and then, serial-diluted and plated on $\mathrm{KB}+\mathrm{Rf}$ to obtain $\mathrm{CFU}$ per milligram of leaf tissue concentrations. Plates were incubated as above. The remaining portion of the four leaves were also weighed, were divided between two homogenizer tubes, and were flash-frozen in liquid nitrogen in preparation for RNA extraction. This experiment was repeated twice with three biological replicates each.

\section{RNA extraction and RT.}

Whole leaves and punched leaf discs were homogenized under freezing conditions in a GenoGrinder (SPEX SamplePrep, Metuchen, NJ, U.S.A.) and RNA was extracted using Trizol Reagent (Thermo Fisher Scientific, Waltham, MA, U.S. A.), followed by the Direct-Zol Miniprep or Miniprep Plus kits (Zymo Research, Irvine, CA, U.S.A.), which included an oncolumn DNAse I treatment (30 U per column for $15 \mathrm{~min}$ ). RNA was quantified using the BioSpectrometer and $\mu$ Cuvette G1.0 (Eppendorf), and the two paired RNA extractions were pooled together. The resulting total RNA extracted was, therefore, a mix of in-planta bacterial and plant RNAs. For a media-based in-vitro control, $1 \mathrm{ml}$ of the inoculum source was pelleted and RNA was extracted in an identical manner.

For each sample, 4 to $8 \mu \mathrm{g}$ of RNA was reverse-transcribed to cDNA using the qScript cDNA supermix (Quantabio, Beverly, MA, U.S.A.), using $1 \mu \mathrm{g}$ of RNA per $20-\mu$ l reaction as template, the maximum quantity recommended by the kit. A small 
amount of non-reverse transcribed RNA was similarly diluted to $50 \mathrm{ng} / \mu \mathrm{l}$ and was retained to test for genomic DNA carryover. $\mathrm{RT}$ reactions were carried out in the FlexCycler ${ }^{2}$ (Analytik Jena AG, Jena, Germany), following Quanta's recommended thermal cycling protocol $\left(5 \mathrm{~min}\right.$ at $25^{\circ} \mathrm{C}, 30 \mathrm{~min}$ at $42^{\circ} \mathrm{C}, 5 \mathrm{~min}$ at $85^{\circ} \mathrm{C}$, hold at $4^{\circ} \mathrm{C}$ ). After RT, multiple reactions for individual samples were pooled, aliquoted, and stored at $-80^{\circ} \mathrm{C}$ until use. We found that repeat freeze-thaws of pooled, nonaliquoted cDNA resulted in serious reductions in cDNA concentrations, as determined by RT-qPCR. Prealiquoting neat cDNA in volumes specific to individual tests ensured equal treatment of transcripts across multi-plate experiments. Dilutions of cDNA to be used in RT-qPCR were prepared in sterile water, on ice or cool blocks, and were held at $4^{\circ} \mathrm{C}$ for up to $24 \mathrm{~h}$.

\section{RT-qPCR.}

Selection of target genes and primer design. Custom RTqPCR primers were designed to amplify approximately 100-bp fragments of their target genes based on GenBank accessions for P. syringae pv. tomato DC3000 (National Center for Biotechnology Information reference sequence NC_004578.1), with specifications for a melting temperature of $60^{\circ} \mathrm{C}$. For bacterial RNA quantification, a novel $16 \mathrm{~S}$ primer set was designed to bind in $16 \mathrm{~S}$ variable regions 1 and 2 for high $P$. syringae specificity. In pseudomonads, 16S variable region 1 has been shown to be hypervariable, which aided in the design of specific primers (Bodilis et al. 2012). A synthetic double-stranded DNA gBlock (Integrated DNA Technologies, Coralville, IA, U.S.A.) was used as a standard for quantification of $P$. syringae-specific $16 \mathrm{~S}$ rRNA. The gBlock included the entire amplicon, with small flanks on either side, for a total length of $125 \mathrm{bp}$ (Table 1). The gBlock was dissolved in $1 \times$ Tris-EDTA (TE) to $2.5 \mathrm{ng} / \mu \mathrm{l}$, and then, was further diluted in sterile water to $1 \mathrm{ng} / \mu \mathrm{l}$ and beyond in a fivefold serial dilution.

To target RG candidates, we used previously published qPCR primers for hemD (Freeman et al. 2013) and rpoD (GonzálezLamothe et al. 2012) and designed primers to target gyrA, gap-1, and recA. The remaining four RG candidates, cynT, lcs- 1 , leuD, and $o p r F$ were observed as highly expressed and stable in Flg22-pretreated and naïve infected plant tissues from preliminary RNA-Seq analysis (unpublished). To target GOI, we designed primers for $h r p A l$ and $f l i C$ and used previously published primers targeting $c f l$ (Worley et al. 2013) to amplify under similar conditions (Table 1). Primers were ordered from Integrated DNA Technologies, were dissolved in $1 \times$ TE to $100 \mu \mathrm{M}$, and were then diluted to $10 \mu \mathrm{M}$ in sterile water for use in PCR. All working stocks of primers and the gBlock were pre-aliquoted for individual use and were stored at $-20^{\circ} \mathrm{C}$.

$R T-q P C R$ pretests. Conditions of RT-qPCR were kept identical throughout all runs. Amplification of cDNA was performed in 10- $\mu$ l reactions, using Veriquest SYBR green qPCR master mix (Thermo Fisher Scientific), $0.25 \mu \mathrm{M}$ primers, and $2 \mu \mathrm{l}$ of cDNA at varying concentrations, depending on one or both the treatment or target. Master mixes and primers were pre-aliquoted for single use and were stored at $-20^{\circ} \mathrm{C}$. New, frozen aliquots of sample cDNA were diluted fresh, as needed, in sterile water for all reactions that could be run in a single day and were never reused. PCR cocktails and plates were prepared on ice or cool blocks and were stored in the dark until ready to run for no more than $12 \mathrm{~h}$. All PCR reactions were run in triplicate wells. We followed the default thermal cycling protocol in the StepOne software v2.3 (Thermo Fisher Scientific) with real-time capture of SYBR green and ROX (passive reference) fluorescence as follows: $10 \mathrm{~min}$ at $90^{\circ} \mathrm{C}$, followed by 40 cycles of $95^{\circ} \mathrm{C}$ for $15 \mathrm{~s}$ and $60^{\circ} \mathrm{C}$ for $1 \mathrm{~min}$, with camera capture at the end of each cycle. A melt curve was generated after the 40th cycle, using these parameters: $95^{\circ} \mathrm{C}$ for $15 \mathrm{~s}, 60^{\circ} \mathrm{C}$ for
$1 \mathrm{~min}$, then a slow ramp $\left(0.3^{\circ} \mathrm{C}\right.$ per second $)$ to $95^{\circ} \mathrm{C}$, with camera capture. All runs were conducted on the Step One Plus real-time PCR system (Thermo Fisher Scientific).

To estimate the amplification efficiency $\left(E_{\text {est }}\right)$ of the newly designed 16S rRNA primers, a standard curve was generated in Excel 2016 (Microsoft), using 1:5 serial dilutions of in-vitro bacterial cDNA amplified with $P$. syringae-specific $16 \mathrm{~S}$ rRNA primers. It was found that PCR reactions containing $0.016 \times$ $10^{-6}$ to $5.12 \times 10^{-6} \mathrm{ng}$ of pure bacterial cDNA could yield an optimal range of $\mathrm{C}_{\mathrm{q}}$ values from 13.6 to 24.9, and the slope of the curve $(m)$ generated by plotting the log of nanograms of cDNA against the resulting $\mathrm{C}_{\mathrm{q}}$ would estimate a good efficiency in pure bacteria $\left(105.08 \%, \mathrm{R}^{2}=0.9972\right)$, using the following formula.

$$
E_{\text {est }}=10^{-1 / m}-1
$$

To test the amplification efficiency of the $16 \mathrm{~S}$ primers in mixed plant and bacterial cDNA and to determine relative concentrations of bacterial cDNA derived from mixed total RNAs, we infected plants, as described above, with decreasing concentrations of inoculum (approximately $1 \times 10^{9}, 3 \times 10^{8}, 1 \times 10^{8}, 3 \times 10^{7}, 1 \times 10^{7}$, and $3 \times 10^{6} \mathrm{CFU} / \mathrm{ml}$ ) for $2 \mathrm{~h}$ and performed RNA extractions and RT synthesis as described above. cDNA was serially diluted 1:5 from $2 \mathrm{ng} / \mu \mathrm{l}$, and three dilutions, from 0.4 to $0.016 \mathrm{ng}$ per reaction, were tested with the $16 \mathrm{~S}$ primers. $\mathrm{C}_{\mathrm{q}}$ values were plotted against the $\log _{10}$ of nanograms of cDNA and the $E_{\text {est }}$ was calculated from the slope of the curves. All six samples showed $\mathrm{E}_{\mathrm{est}}$ within somewhat acceptable ranges (94 to $114 \%$ ), with good $\mathrm{R}^{2}$ values (0.9911 to 1 ) for correlation coefficients.

To verify that all endogenous gene primer pairs used in the study showed 90 to $110 \%$ efficiency, pure bacterial cDNA was serially diluted 1:5 from 10 and $2 \mathrm{ng} / \mu \mathrm{l}$ to create a range of concentrations from 20.0 to $0.0032 \mathrm{ng}$ per reaction. A series of these dilutions were amplified with each of nine candidate RG primer sets.

Sample quantification and $R G$ validation. For RT-qPCR, a new eight-point standard curve was generated using one-fifth serial dilutions of the $16 \mathrm{~S}$ gBlock amplified with the $P$. syringaespecific $16 \mathrm{~S}$ rRNA primers, ranging from $0.016 \times 10^{-7}$ to $2.05 \times$ $10^{-7} \mathrm{ng}$ of cDNA per reaction. In planta and in vitro samples were diluted to a concentration appropriate to detect within a normal $\mathrm{C}_{\mathrm{q}}$ range (approximately $\mathrm{C}_{\mathrm{q}}=20$ to 24 ), as found by preliminary experiments. The bacterial content of all samples was quantified by plotting against the $16 \mathrm{~S}$ standard curve. Concerns regarding carryover of genomic DNA into the RT-qPCR reaction were eliminated by testing equivalent amounts of non-reverse transcribed RNA. Bacterial cDNA quantities detected in the PCR were scaled up to the amount of total RNA converted to cDNA in the first-strand reverse-transcription synthesis. Total cDNA was further scaled up to quantities of extracted total RNA, and the weight of plant tissue used was factored. These quantities, in nanograms $16 \mathrm{~S}$ rRNA per milligram of leaf weight, were plotted against recovered CFU per milligram of leaf weight to show equivalence in detection by plating and PCR (Fig. 1A and B).

To investigate the variation of expression of candidate RGs across samples generated under different conditions, all samples were normalized to $0.6 \mathrm{pg}$ of bacterial rRNA per reaction, a concentration slightly lower than the least-concentrated sample. The normalized samples were tested against all nine RG primer pairs and a 1:1,250 dilution was tested against the $16 \mathrm{~S}$ primer pairs, as well, to confirm normalization. Data were trimmed to remove outliers within the StepOne software: individual reactions that contributed to an average $C_{q}$ with a standard deviation (SD) higher than 0.3 were removed. Individual wells that showed aberrant amplification curves, especially those in corner wells or with very high starting concentrations of template, were also removed, even if their SD was below 0.3 , because downstream analysis may derive incorrect 
baseline values from them. To determine $\mathrm{C}_{\mathrm{q}}$ and calculate empiric PCR efficiency $\left(E_{e m p}\right)$, raw amplification data $(R n$ values) were input to LRP version January2016, available from the Heart Failure Research Center. Baselines were determined according to default settings, and the window of linearity (WOL) was set to establish a baseline via linear regression for each amplicon. If samples showed baseline errors, the errors were ignored and samples were allowed to remain in the dataset but would not contribute to the mean efficiency as derived by the LRP software $\left(\mathrm{E}_{\mathrm{emp}}\right)$. The mean $\mathrm{C}_{\mathrm{q}}$ values of triplicate wells for each RG and sample were input to RefFinder, available from the cotton EST database. This software ranks RGs across multiple algorithms for stability (Fig. 2). We ran the same $\mathrm{Cq}$ values, along with $\mathrm{E}_{\mathrm{emp}}$ values from LRP in the SLqPCR package (R), which similarly processes these data for stability, using the GeNorm algorithm; reference genes scored identically in this test. From these tests, we were able to select our four top RGs, oprF, recA, leuD, and rpoD. We chose to use oprF and recA in subsequent PCRs because they scored as most stable across RefFinder's meta-analysis and demonstrated normal $(o p r F)$ and late $(r e c A) \mathrm{C}_{\mathrm{q}}$ ranges, representing mid- and low-expressed transcripts, respectively. Analysis using the $\mathrm{R}$ packgae produced identical results.

GOI. We tested normalized cDNA from five treatments: in vitro bacteria, mock-treated $5 \mathrm{~h}$ with infecting bacteria, Flg22pretreated $5 \mathrm{~h}$ with infecting bacteria, mock-treated $24 \mathrm{~h}$ with infecting bacteria, and Flg22-pretreated $24 \mathrm{~h}$ with infecting bacteria). We used three biological replicates each from duplicated experiments. One sample in the Flg22, 5-h set was discarded from analysis due to consistently aberrant results, most likely due to incomplete Flg22 pretreatment. These samples were tested for relative expression of three GOI: coronafacic acid ligase $(c f l)$, flagellin $(f l i C)$, and the type III secretion system pilin protein $(h r p A l)$. Samples were grouped by biological replicate set and were tested against the three GOI, the two RGs, and 16S rRNA within the same plate. Pairing GOI with RGs and treatment samples to controls should be prioritized over more convenient groupings within a single plate, as variation between runs can complicate all calculations. This became evident when results of identical samples in different runs showed wide swings in $\mathrm{C}_{\mathrm{q}}$ values.

Measurement and analysis of relative expression. Individual data were trimmed in StepOne software to eliminate outliers, and the raw amplification data from these trimmed samples were input to LRP. Using the baseline and WOL settings described above, sample $\mathrm{C}_{\mathrm{q}}$ and mean $\mathrm{E}_{\mathrm{emp}}$ were determined. The NRQ of a GOI was calculated using $\mathrm{E}_{\mathrm{emp}}$ and $\mathrm{C}_{\mathrm{q}}$ values from LRP via a modified Pfaffl equation (Hellemans et al. 2007; Pfaffl 2001) to include the geometric mean of both RGs in the denominator, as follows.

$$
N R Q=\frac{E_{G O I}^{\left(C q_{\text {control }}-C q_{\text {treatment }}\right)^{G O I}}}{\prod E_{R G}^{\left(C q_{\text {control }}-C q_{\text {treatment }}\right)^{R G}}}
$$

$\mathrm{C}_{\mathrm{q}}$ values of three technical replicates were averaged and the NRQ of five to six biological replicates was calculated individually, so that GOI and RG values could be paired appropriately for data collected within runs. For each GOI, we performed two-tailed $t$ tests assuming equal variances in MATLAB and Statistics Toolbox release 2012b (The Mathworks, Inc., Natick, MA, U.S.A.) to test the null hypothesis that the means of NRQ values between treatments were equal. The null hypotheses of $t$ tests were rejected at the 5\% significance level $(P<0.05)$ (Fig. 3).

\section{ACKNOWLEDGMENTS}

We gratefully acknowledge the assistance of I. Major with statistical guidance, M. Brewer for use of the GenoGrinder and I. Major and
B. Swingle for helpful discussion and comments regarding the preparation of this manuscript. This work was supported by funds from the National Institute of Food and Agriculture Hatch grant (project GEO00791) and the State of Georgia. The funders had no role in the design of this study, analysis and interpretation of data, or decision to submit results.

\section{LITERATURE CITED}

Boch, J., Joardar, V., Gao, L., Robertson, T. L., Lim, M., and Kunkel, B. N. 2002. Identification of Pseudomonas syringae pv. tomato genes induced during infection of Arabidopsis thaliana. Mol. Microbiol. 44:73-88.

Bodilis, J., Nsigue-Meilo, S., Besaury, L., and Quillet, L. 2012. Variable copy number, intra-genomic heterogeneities and lateral transfers of the 16S rRNA gene in Pseudomonas. PLoS One 7:e35647.

Boller, T., and Felix, G. 2009. A renaissance of elicitors: Perception of microbe-associated molecular patterns and danger signals by patternrecognition receptors. Annu. Rev. Plant Biol. 60:379-406.

Bombarely, A., Rosli, H. G., Vrebalov, J., Moffett, P., Mueller, L. A., and Martin, G. B. 2012. A draft genome sequence of Nicotiana benthamiana to enhance molecular plant-microbe biology research. Mol. PlantMicrobe Interact. 25:1523-1530.

Bremer, H., and Dennis, P. P. 2008. Modulation of chemical composition and other parameters of the cell at different exponential growth rates. Ecosal Plus 3. Published online.

Buell, C. R., Joardar, V., Lindeberg, M., Selengut, J., Paulsen, I. T., Gwinn, M. L., Dodson, R. J., Deboy, R. T., Durkin, A. S., Kolonay, J. F., Madupu, R., Daugherty, S., Brinkac, L., Beanan, M. J., Haft, D. H., Nelson, W. C., Davidsen, T., Zafar, N., Zhou, L., Liu, J., Yuan, Q., Khouri, H., Fedorova, N., Tran, B., Russell, D., Berry, K., Utterback, T., Van Aken, S. E., Feldblyum, T. V., D’Ascenzo, M., Deng, W. L., Ramos, A. R., Alfano, J. R., Cartinhour, S., Chatterjee, A. K., Delaney, T. P., Lazarowitz, S. G., Martin, G. B., Schneider, D. J., Tang, X., Bender, C. L., White, O., Fraser, C. M., and Collmer, A. 2003. The complete genome sequence of the Arabidopsis and tomato pathogen Pseudomonas syringae pv. tomato DC3000. Proc. Natl. Acad. Sci. U.S.A. 100:10181-10186.

Bustin, S. A., Benes, V., Garson, J. A., Hellemans, J., Huggett, J., Kubista, M., Mueller, R., Nolan, T., Pfaffl, M. W., Shipley, G. L., Vandesompele, J., and Wittwer, C. T. 2009. The MIQE guidelines: Minimum information for publication of quantitative real-time PCR experiments. Clin. Chem. 55:611-622.

Chatnaparat, T., Li, Z., Korban, S. S., and Zhao, Y. 2015. The stringent response mediated by (p)ppGpp is required for virulence of Pseudomonas syringae pv. tomato and its survival on tomato. Mol. Plant-Microbe Interact. 28:776-789.

Crabill, E., Joe, A., Block, A., van Rooyen, J. M., and Alfano, J. R. 2010. Plant immunity directly or indirectly restricts the injection of type III effectors by the Pseudomonas syringae type III secretion system. Plant Physiol. 154:233-244.

Ferreira, A. O., Myers, C. R., Gordon, J. S., Martin, G. B., Vencato, M., Collmer, A., Wehling, M. D., Alfano, J. R., Moreno-Hagelsieb, G., Lamboy, W. F., DeClerck, G., Schneider, D. J., and Cartinhour, S. W. 2006. Whole-genome expression profiling defines the HrpL regulon of Pseudomonas syringae pv. tomato DC3000, allows de novo reconstruction of the Hrp cis clement, and identifies novel coregulated genes. Mol. Plant-Microbe Interact. 19:1167-1179.

Filiatrault, M. J., Stodghill, P. V., Myers, C. R., Bronstein, P. A., Butcher, B. G., Lam, H., Grills, G., Schweitzer, P., Wang, W., Schneider, D. J., and Cartinhour, S. W. 2011. Genome-wide identification of transcriptional start sites in the plant pathogen Pseudomonas syringae pv. tomato str. DC3000. PLoS One 6:e29335.

Freeman, B. C., Chen, C., Yu, X., Nielsen, L., Peterson, K., and Beattie, G. A. 2013. Physiological and transcriptional responses to osmotic stress of two Pseudomonas syringae strains that differ in epiphytic fitness and osmotolerance. J. Bacteriol. 195:4742-4752.

González-Lamothe, R., El Oirdi, M., Brisson, N., and Bouarab, K. 2012. The conjugated auxin indole-3-acetic acid-aspartic acid promotes plant disease development. Plant Cell 24:762-777.

Hellemans, J., Mortier, G., De Paepe, A., Speleman, F., and Vandesompele, J. 2007. qBase relative quantification framework and software for management and automated analysis of real-time quantitative PCR data. Genome Biol. 8:R19.

Ishiga, Y., and Ichinose, Y. 2016. Pseudomonas syringae pv. tomato OxyR is required for virulence in tomato and Arabidopsis. Mol. Plant-Microbe Interact. 29:119-131.

Jones, J. D. G., and Dangl, J. L. 2006. The plant immune system. Nature 444:323-329.

Katsir, L., Schilmiller, A. L., Staswick, P. E., He, S. Y., and Howe, G. A. 2008. COI1 is a critical component of a receptor for jasmonate and the bacterial virulence factor coronatine. Proc. Natl. Acad. Sci. U.S.A. 105:7100-7105. 
King, E. O., Ward, M. K., and Raney, D. E. 1954. Two simple media for the demonstration of pyocyanin and fluorescin. J. Lab. Clin. Med. 44: 301-307.

Kozera, B., and Rapacz, M. 2013. Reference genes in real-time PCR. J. Appl. Genet. 54:391-406.

Lee, J. S., Ryu, H. R., Cha, J. Y., and Baik, H. S. 2015. The hrp pathogenicity island of Pseudomonas syringae pv. tomato DC3000 is induced by plant phenolic acids. J. Microbiol. 53:725-731.

Lindeberg, M., Biehl, B. S., Glasner, J. D., Perna, N. T., Collmer, A., and Collmer, C. W. 2009. Gene Ontology annotation highlights shared and divergent pathogenic strategies of type III effector proteins deployed by the plant pathogen Pseudomonas syringae pv tomato DC3000 and animal pathogenic Escherichia coli strains. BMC Microbiol. 9 (Suppl 1):S4.

Livak, K. J., and Schmittgen, T. D. 2001. Analysis of relative gene expression data using real-time quantitative PCR and the $2^{-\Delta \Delta} \mathrm{C}(\mathrm{T})$ method. Methods 25:402-408.

MacLean, D., and Studholme, D. J. 2010. A Boolean model of the Pseudomonas syringae hrp regulon predicts a tightly regulated system. PLoS One 5:e9101.

Mascia, T., Santovito, E., Gallitelli, D., and Cillo, F. 2010. Evaluation of reference genes for quantitative reverse-transcription polymerase chain reaction normalization in infected tomato plants. Mol. Plant Pathol. 11:805-816.

Mittal, S., and Davis, K. R. 1995. Role of the phytotoxin coronatine in the infection of Arabidopsis thaliana by Pseudomonas syringae pv. tomato. Mol. Plant-Microbe Interact. 8:165-171.

Newman, M. A., Sundelin, T., Nielsen, J. T., and Erbs, G. 2013. MAMP (microbe-associated molecular pattern) triggered immunity in plants. Front. Plant Sci. 4:139.

Nishimura, M. T., and Dangl, J. L. 2010. Arabidopsis and the plant immune system. Plant J. 61:1053-1066.

Pabinger, S., Rödiger, S., Kriegner, A., Vierlinger, K., and Weinhäusel, A. 2014. A survey of tools for the analysis of quantitative PCR (qPCR) data. Biomol Detect Quantif 1:23-33.

Petriccione, M., Mastrobuoni, F., Zampella, L., and Scortichini, M. 2015. Reference gene selection for normalization of RT-qPCR gene expression data from Actinidia deliciosa leaves infected with Pseudomonas syringae pv. actinidiae. Sci. Rep. 5:16961.

Pfaffl, M. W. 2001. A new mathematical model for relative quantification in real-time RT-PCR. Nucleic Acids Res. 29:e45.

Records, A. R., and Gross, D. C. 2010. Sensor kinases RetS and LadS regulate Pseudomonas syringae type VI secretion and virulence factors. J. Bacteriol. 192:3584-3596.

Scholtz, J. J., and Visser, B. 2013. Reference gene selection for qPCR gene expression analysis of rust-infected wheat. Physiol. Mol. Plant Pathol. $81: 22-25$.

Schreiber, K. J., and Desveaux, D. 2011. AlgW regulates multiple Pseudomonas syringae virulence strategies. Mol. Microbiol. 80:364-377.

Tegli, S., Gori, A., Cerboneschi, M., Cipriani, M. G., and Sisto, A. 2011. Type three secretion system in Pseudomonas savastanoi pathovars: Does timing matter? Genes (Basel) 2:957-979.
Vandesompele, J., De Preter, K., Pattyn, F., Poppe, B., Van Roy, N., De Paepe, A., and Speleman, F. 2002. Accurate normalization of real-time quantitative RT-PCR data by geometric averaging of multiple internal control genes. Genome Biol. 3:0034.

Vargas, P., Farias, G. A., Nogales, J., Prada, H., Carvajal, V., Barón, M., Rivilla, R., Martín, M., Olmedilla, A., and Gallegos, M.-T. 2013. Plant flavonoids target Pseudomonas syringae pv. tomato DC3000 flagella and type III secretion system. Environ. Microbiol. Rep. 5:841-850.

Wei, H. L., Chakravarthy, S., Worley, J. N., and Collmer, A. 2013. Consequences of flagellin export through the type III secretion system of Pseudomonas syringae reveal a major difference in the innate immune systems of mammals and the model plant Nicotiana benthamiana. Cell. Microbiol. 15:601-618.

Wei, W., Plovanich-Jones, A., Deng, W. L., Jin, Q. L., Collmer, A., Huang, H. C., and He, S. Y. 2000. The gene coding for the Hrp pilus structural protein is required for type III secretion of Hrp and Avr proteins in Pseudomonas syringae pv. tomato. Proc. Natl. Acad. Sci. U.S.A. 97: 2247-2252.

Worley, J. N., Russell, A. B., Wexler, A. G., Bronstein, P. A., Kvitko, B. H., Krasnoff, S. B., Munkvold, K. R., Swingle, B., Gibson, D. M., and Collmer, A. 2013. Pseudomonas syringae pv. tomato DC3000 CmaL (PSPTO4723), a DUF1330 family member, is needed to produce L-alloisoleucine, a precursor for the phytotoxin coronatine. J. Bacteriol. 195: 287-296.

Xin, X. F., and He, S. Y. 2013. Pseudomonas syringae pv. tomato DC3000: A model pathogen for probing disease susceptibility and hormone signaling in plants. Annu. Rev. Phytopathol. 51:473-498.

Yu, X., Lund, S. P., Scott, R. A., Greenwald, J. W., Records, A. H., Nettleton, D., Lindow, S. E., Gross, D. C., and Beattie, G. A. 2013. Transcriptional responses of Pseudomonas syringae to growth in epiphytic versus apoplastic leaf sites. Proc. Natl. Acad. Sci. U.S.A. 110:E425-E434.

Zeng, W., Brutus, A., Kremer, J. M., Withers, J. C., Gao, X., Jones, A. D., and He, S. Y. 2011. A genetic screen reveals Arabidopsis stomatal and/or apoplastic defenses against Pseudomonas syringae pv. tomato DC3000. PLoS Pathog. 7:e1002291.

Zhang, L., Yao, J., Withers, J., Xin, X. F., Banerjee, R., Fariduddin, Q., Nakamura, Y., Nomura, K., Howe, G. A., Boland, W., Yan, H., and He, S. Y. 2015. Host target modification as a strategy to counter pathogen hijacking of the jasmonate hormone receptor. Proc. Natl. Acad. Sci. U.S.A. 112:14354-14359.

Zheng, X. Y., Spivey, N. W., Zeng, W., Liu, P.-P., Fu, Z. Q., Klessig, D. F., He, S. Y., and Dong, X. 2012. Coronatine promotes Pseudomonas syringae virulence in plants by activating a signaling cascade that inhibits salicylic acid accumulation. Cell Host Microbe 11:587-596.

Zipfel, C., and Robatzek, S. 2010. Pathogen-associated molecular patterntriggered immunity: Veni, vidi...? Plant Physiol. 154:551-554.

Zipfel, C., Robatzek, S., Navarro, L., Oakeley, E. J., Jones, J. D., Felix, G., and Boller, T. 2004. Bacterial disease resistance in Arabidopsis through flagellin perception. Nature 428:764-767. 